\title{
Capacity Enhancement of Aqueous Borohydride Fuels for hydrogen storage in liquids
}

David Schubert, Doinita Neiner, Mark Bowden, Sean Whittemore, Jamie Holladay, Zhenguo Huang and Tom Autrey

\author{
${ }^{1}$ U.S. Borax Inc., Rio Tinto, Greenwood Village, CO, USA \\ ${ }^{2}$ Pacific Northwest National Laboratory, Richland, WA, USA \\ ${ }^{3}$ University of Wollongong, Australia
}

\begin{abstract}
In this work we demonstrate enhanced hydrogen storage capacities through increased solubility of sodium borate product species in aqueous media achieved by adjusting the sodium $(\mathrm{NaOH})$ to boron $\left(\mathrm{B}(\mathrm{OH})_{3}\right)$ ratio, i.e., $\mathrm{M} / \mathrm{B}$, to obtain a distribution of polyborate anions. For a 1:1 mole ratio of $\mathrm{NaOH}$ to $\mathrm{B}(\mathrm{OH})_{3}, \mathrm{M} / \mathrm{B}=1$, the ratio of the hydrolysis product formed from $\mathrm{NaBH}_{4}$ hydrolysis, the sole borate species formed and observed by ${ }^{11} \mathrm{~B}$ NMR is sodium metaborate, $\mathrm{NaB}(\mathrm{OH})_{4}$. When the ratio is $1: 3 \mathrm{NaOH}$ to $\mathrm{B}(\mathrm{OH})_{3}, \mathrm{M} / \mathrm{B}=0.33$, a mixture of borate anions is formed and observed as a broad peak in the ${ }^{11} \mathrm{~B}$ NMR spectrum. The complex polyborate mixture yields a metastable solution that is difficult to crystallize. Given the enhanced solubility of the polyborate mixture formed when $\mathrm{M} / \mathrm{B}=0.33$ it should follow that the hydrolysis of sodium octahydrotriborate, $\mathrm{NaB}_{3} \mathrm{H}_{8}$, can provide a greater storage capacity of hydrogen for fuel cell applications compared to sodium borohydride while maintaining a single phase. Accordingly, the hydrolysis of a $23 \mathrm{wt} \% \mathrm{NaB}_{3} \mathrm{H}_{8}$ solution in water yields a solution having the same complex polyborate mixture as formed by mixing a 1:3 molar ratio of $\mathrm{NaOH}$ and $\mathrm{B}(\mathrm{OH})_{3}$ and releases $>8$ eq of $\mathrm{H}_{2}$. By optimizing the $\mathrm{M} / \mathrm{B}$ ratio a complex mixture of soluble products, including $\mathrm{B}_{3} \mathrm{O}_{3}(\mathrm{OH})_{5}{ }^{2-}, \mathrm{B}_{4} \mathrm{O}_{5}(\mathrm{OH})_{4}{ }^{2-}, \mathrm{B}_{3} \mathrm{O}_{3}(\mathrm{OH})_{4}{ }^{-}, \mathrm{B}_{5} \mathrm{O}_{6}(\mathrm{OH})_{4}{ }^{-}$and $\mathrm{B}(\mathrm{OH})_{3}$, can be maintained as a single liquid phase throughout the hydrogen release process. Consequently, hydrolysis of $\mathrm{NaB}_{3} \mathrm{H}_{8}$ can provide a $40 \%$ increase in $\mathrm{H}_{2}$ storage density compared to the hydrolysis of $\mathrm{NaBH}_{4}$ given the decreased solubility of sodium metaborate.
\end{abstract}

Key words: liquid hydrogen storage, solubility, polyborate mixtures. 


\section{$\underline{1 . \text { Introduction }}$}

The US DoE Fuel Cell Technologies Office recently released a new set of hydrogen storage metrics and targets for non-vehicular applications ranging from materials handling equipment, e.g., fork lifts and airport tugs, to portable power equipment (PPE), e.g., battery chargers and Unmanned Aerial Vehicles. ${ }^{1}$ Specifically, the new gravimetric (40 $\mathrm{g} \mathrm{H}_{2} / \mathrm{kg}$ system) and volumetric (50 $\mathrm{g} \mathrm{H}_{2} /$ liter system) hydrogen storage targets for single charge PPE present new opportunities for materials discovery. One approach that has a strong appeal for both PPE and vehicular applications are liquid carriers. ${ }^{2-9}$ Liquid hydrogen carriers offer attractive options for hydrogen storage materials given their ease of transfer to and from devices using pumps and pipes in existing infrastructure, as well as ease of transfer within devices (e.g., from a storage tank to a reactor).

Hydrolysis of borohydrides and ammonia borane has been investigated to evaluate the potential of aqueous liquid carriers. ${ }^{10-13}$ Aqueous sodium borohydride (SBH) in particular has been researched extensively ${ }^{14}$ as a liquid hydrogen carrier because it is highly soluble in water $(360 \mathrm{~g} / \mathrm{L})$ with a theoretical gravimetric capacity of $7.3 \mathrm{wt} . \% \mathrm{H}_{2}$ :

$$
\mathrm{NaBH}_{4}+4 \mathrm{H}_{2} \mathrm{O} \rightarrow \mathrm{NaB}(\mathrm{OH})_{4}+4 \mathrm{H}_{2}
$$

However, a major shortcoming in the $\mathrm{NaBH}_{4}$ approach is the failure to remain liquid throughout the entire hydrogen release cycle at high loadings since additional water is required to keep the sodium metaborate hydrolysis product soluble. The Hydrogen-on-Demand, HOD®, system was developed for vehicular applications using 20-30 wt.\% solutions of $\mathrm{NaBH}_{4}$ (ca. 4-6.5 wt $\%$ hydrogen on a material basis). Anything greater than 20 wt. $\% \mathrm{NaBH}_{4}$, i.e., $4.5 \mathrm{wt} \% \mathrm{H}_{2}$, presents a challenge to maintain a single liquid phase because of the solubility limit of sodium metaborate (SMB) and led to the DOE curtailing research on aqueous $\mathrm{NaBH}_{4}$ for vehicular applications.

Starting with the known solubility of hydrolysis product: i.e, $590 \mathrm{~g}(5.8$ moles $) \mathrm{NaB}(\mathrm{OH})_{4}$ in a 1 liter saturated solution at $60{ }^{\circ} \mathrm{C}$ one can work backward to determine the quantity of extra water that is required to maintain a liquid phase starting from SBH and ending with SMB. This approach shows that the aqueous solution needs to 'provide or carry' a minimum 3.5 extra 
equivalents of water to keep the products in solution at $60{ }^{\circ} \mathrm{C}$, corresponding to a maximum hydrogen capacity of $4.6 \mathrm{wt} . \%$ as illustrated in equation 2.

$$
\mathrm{NaBH}_{4}+4 \mathrm{H}_{2} \mathrm{O}+3.5 \mathrm{H}_{2} \mathrm{O} * \rightarrow \mathrm{NaB}(\mathrm{OH})_{4}+4 \mathrm{H}_{2}+3.5 \mathrm{H}_{2} \mathrm{O} *
$$

It is notable that 1 liter of solution containing $590 \mathrm{~g} \mathrm{NaB}(\mathrm{OH})_{4}$ remains a liquid yet only yields $4.6 \mathrm{wt} \% \mathrm{H}_{2}$. The challenge thus lies in approaches to prepare solutions of borates that will remain soluble on scales $>\sim 600 \mathrm{~g}$ of a borate salt in a saturated solution.

A survey of the literature shows that the solubility of sodium borates varies dramatically as a function of the Na/B ratio (Fig. 1) ${ }^{15}$ At $60{ }^{\circ} \mathrm{C}$ there is a maximum solubility near $\mathrm{Na} / \mathrm{B}=0.31$. The reason for this is that there is not a simple borate anion formed to charge-balance sodium; instead a complex mixture of polyborate anions is formed through a series of condensation equilibria: ${ }^{16}$

$$
\begin{aligned}
& \mathrm{B}(\mathrm{OH})_{3}+\mathrm{OH}^{-} \leftrightarrow \mathrm{B}(\mathrm{OH})_{4}^{-} \\
& \mathrm{B}(\mathrm{OH})_{3}+2 \mathrm{~B}(\mathrm{OH})_{4}^{-} \leftrightarrow \mathrm{B}_{3} \mathrm{O}_{3}(\mathrm{OH})_{5}^{-}+3 \mathrm{H}_{2} \mathrm{O} \\
& 2 \mathrm{~B}(\mathrm{OH})_{3}+2 \mathrm{~B}(\mathrm{OH})_{4}^{-} \leftrightarrow+\mathrm{B}_{4} \mathrm{O}_{5}(\mathrm{OH})_{4}{ }^{2-}+5 \mathrm{H}_{2} \mathrm{O} \\
& 2 \mathrm{~B}(\mathrm{OH})_{3}+\mathrm{B}(\mathrm{OH})_{4}^{-} \leftrightarrow \mathrm{B}_{3} \mathrm{O}_{3}(\mathrm{OH})_{4}^{-}+3 \mathrm{H}_{2} \mathrm{O} \\
& 4 \mathrm{~B}(\mathrm{OH})_{3}+\mathrm{B}(\mathrm{OH})_{4}^{-} \leftrightarrow \mathrm{B}_{5} \mathrm{O}_{6}(\mathrm{OH})_{4}^{-}+6 \mathrm{H}_{2} \mathrm{O}
\end{aligned}
$$

Our hypothesis is that this mixture of borate anions will not readily undergo a phase change during the reaction and minimize or delay crystallization through an inverse corollary of the common ion effect. We therefore considered borohydrides where the $\mathrm{Na} / \mathrm{B}$ ratio is close to the 0.31 maximum in Figure 1. There are a large number of boron hydrides species, ${ }^{17,18}$ however, the candidates with the most potential include $\mathrm{Na}\left[\mathrm{B}_{4} \mathrm{H}_{9}\right](\mathrm{Na} / \mathrm{B}=0.25)$ and $\mathrm{Na}\left[\mathrm{B}_{3} \mathrm{H}_{8}\right](\mathrm{Na} / \mathrm{B}=0.33)$.

Shore and co-workers have recently shown that hydrolysis of sodium octahydrotriborate, $\mathrm{NaB}_{3} \mathrm{H}_{8}$ provides 9 equivalents of $\mathrm{H}_{2} \cdot{ }^{19,20}$ Furthermore they note that aqueous solutions of $\mathrm{NaB}_{3} \mathrm{H}_{8}$ are more stable than aqueous solutions of $\mathrm{NaBH}_{4}$, a desirable feature for practical hydrogen storage carriers. Based on our analysis of sodium polyborate solubility, we suggest that the hydrolysis of $\mathrm{NaB}_{3} \mathrm{H}_{8}$ can be carried out under concentrated conditions; i.e., only 2 extra equivalents of water are required: 


$$
\mathrm{NaB}_{3} \mathrm{H}_{8}+10 \mathrm{H}_{2} \mathrm{O}+2 \mathrm{H}_{2} \mathrm{O}^{*} \rightarrow \mathrm{Na}^{+}+3 \mathrm{BO}_{2}^{-}+2 \mathrm{H}^{+}+9 \mathrm{H}_{2}+2 \mathrm{H}_{2} \mathrm{O}^{*}
$$

This corresponds to a $23 \mathrm{wt} . \%$ solution of $\mathrm{NaB}_{3} \mathrm{H}_{8}$ in water and a hydrogen capacity of 6.5 wt.\%. Hypothetical $\mathrm{BO}_{2}^{-}$and $\mathrm{H}^{+}$are shown in this equation for simplicity, but in practice the hydrolysis products will contain the polyborate anions shown in equations 3 and further water will be generated in condensation reactions to aid solubility. Thus we anticipate increased solubility of both the polyborate hydrolysis products and the $\mathrm{NaB}_{3} \mathrm{H}_{8}$, which has a reported aqueous solubility of $74 \mathrm{wt} . \%$.

In this report we test the hypothesis of the 'reverse engineering' approach by confirming the solubility of the corresponding polyborate hydrolysis products for a ratio of $\mathrm{Na} / \mathrm{B}=1 / 3$ by preparing surrogate products from 1 to 3 stoichiometric mixtures of $\mathrm{NaOH}$ and $\mathrm{B}(\mathrm{OH})_{3}$ and measuring hydrogen release from aqueous solutions of $\mathrm{NaB}_{3} \mathrm{H}_{8}$ at concentrations necessary to deliver $6.5 \mathrm{wt} \% \mathrm{H}_{2}$ from a liquid fuel.

\section{Materials and methods}

2.1 Synthesis of $\mathrm{NaB}_{3} \underline{\mathrm{H}_{8}}$ : Solvent-free $\mathrm{NaB}_{3} \mathrm{H}_{8}$ was synthesized according to a published literature proceedure. ${ }^{21} \mathrm{~A} \mathrm{Na} / \mathrm{Hg}$ amalgam was reacted with $\mathrm{THF} \cdot \mathrm{BH}_{3}$ under nitrogen to form $\mathrm{NaBH}_{4}$ and $\mathrm{NaB}_{3} \mathrm{H}_{8}$. After removal of THF and redissolution in diethyl ether, $\mathrm{NaBH}_{4}$ was removed by filtration. The filtrate was concentrated under vacuum to an oil from which $\mathrm{NaB}_{3} \mathrm{H}_{8}$ precipitated upon addition of dichloromethane. Approximately $4.5 \mathrm{~g}$ of the white powder was recovered by filtration and vacuum drying. It is notable that Titov has reported the preparation of a variety of cationic octohydrotriborates, i.e., lithium, potassium, magnesium, calcium and strontium, as solvates of dioxane or diglyme, ${ }^{22}$ while Chong et al. have prepared the unsolvated $\mathrm{Mg}\left(\mathrm{B}_{3} \mathrm{H}_{8}\right)_{2}$ by a diborane-free pathway by thermal decomposition of $\mathrm{Mg}\left(\mathrm{BH}_{4}\right)_{2} \cdot{ }^{23}$

2.2 Solubility measurements: A surrogate solution of the corresponding polyborate solution expected to be formed in the hydrolytic decomposition of $\mathrm{NaB}_{3} \mathrm{H}_{8}$ were prepared from 1 to 3 stoichiometric mixtures of $\mathrm{NaOH}$ and $\mathrm{B}(\mathrm{OH})_{3}$ in various amounts of 'excess' water. For example to simulate the product solution from the reaction of $7.50 \mathrm{~g} \mathrm{NaB}_{3} \mathrm{H}_{8}(0.118 \mathrm{~mol})$ with $21.28 \mathrm{~g}$ reactant $\mathrm{H}_{2} \mathrm{O}(1.18 \mathrm{~mol})$ with $4.12 \mathrm{~g}$ excess water that would yield $6.5 \mathrm{wt} \% \mathrm{H}_{2}, 4.12 \mathrm{~g}$ $\mathrm{H}_{2} \mathrm{O}, 4.73 \mathrm{~g} \mathrm{NaOH}$, and $21.9 \mathrm{~g} \mathrm{~B}(\mathrm{OH})_{3}$ were added in the order listed to a 3-neck flask with 
magnetic stirrer and temperature controller set at $60{ }^{\circ} \mathrm{C}$. The mixture readily formed a clear mobile solution. [Caution: the reaction of $\mathrm{NaOH}$ with $\mathrm{B}(\mathrm{OH})_{3}$ is rather exothermic]. This solution was maintained with stirring at $60{ }^{\circ} \mathrm{C}$ for $24 \mathrm{~h}$ and remained crystal clear.

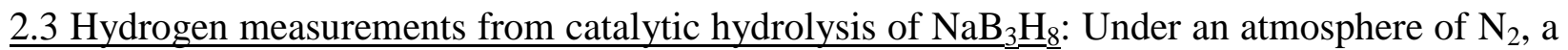
$5 \mathrm{~mL}$ round bottom flask was charged with sodium triborane $(56.2 \mathrm{mg}, 0.885 \mathrm{mmol})$, equipped with a Schlenk adapter, and capped with a rubber septum. The reaction vessel was then connected to a gas burette which included a condenser to prevent moisture contributing to the measurement of gas released. An aqueous solution of $0.253 \mathrm{M} \mathrm{CoCl}_{2}$, prepared under ambient conditions, was then added $(180 \mu \mathrm{L}, 0.0455 \mathrm{mmol}, 5.1 \mathrm{~mol} \%)$ to the reaction vessel. The mixture rapidly released hydrogen and precipitated cobalt nanoparticles. The amount of hydrogen released was found to be 8.7 equivalents in 2 minutes. After no more hydrogen evolved, the mixture was analyzed by ${ }^{11} \mathrm{~B}$ NMR spectroscopy. All of the sodium triborane had been consumed, and the remaining material was a mixture of borates. ${ }^{11} \mathrm{~B} \mathrm{NMR}\left(\mathrm{H}_{2} \mathrm{O}, 160 \mathrm{MHz}\right)$ : 17 11 (br), 0.97 (s) ppm.

\section{Results and Discussion}

Aqueous solutions of the spent fuel compositions of $\mathrm{NaBH}_{4}(\mathrm{Na} / \mathrm{B}=1)$ and $\mathrm{NaB}_{3} \mathrm{H}_{8}(\mathrm{Na} / \mathrm{B} \approx$ 0.33) were prepared to verify whether their hydrolysis products remained soluble under the expected conditions of a hydrogen delivery system. Solid reagents were first dissolved in water at $60{ }^{\circ} \mathrm{C}$ and allowed to cool to room temperature. The results are summarized in Table 1, which confirms the greater solubility of products for $\mathrm{Na} / \mathrm{B} \approx 0.33$. The hydrogen contents for the corresponding aqueous liquid fuels are also shown in Table 1, calculated using the relationships given in Equations 1 and 4. Note that at this stage of analysis we are focusing on product stability and are therefore using theoretical rather than measured hydrogen contents. The $\mathrm{Na} / \mathrm{B}=$ 1 solutions remained clear up to 5.0 wt. $\% \mathrm{H}_{2}$, but showed undissolved solids at $5.2 \mathrm{wt} \% \mathrm{H}_{2}$. By contrast, the $\mathrm{Na} / \mathrm{B} \approx 0.33$ solutions were transparent at $5.4 \mathrm{wt} \% \mathrm{H}_{2}$ and still stirrable, though viscous, at $6.7 \mathrm{wt} \% \mathrm{H}_{2}$. A photograph of the polyborate solution simulating release of $6.35 \% \mathrm{H}_{2}$ $(\mathrm{Na} / \mathrm{B}=0.34)$ is shown in Figure 2 after cooling to room temperature. No precipitation was observed and the solution remained easily stirrable. These results show that more boron-rich sodium borohydride compounds are likely to provide higher hydrogen-containing fuels than 
$\mathrm{NaBH}_{4}$; and in particular that $\mathrm{NaB}_{3} \mathrm{H}_{8}$ is a strong candidate for aqueous fuels containing greater than 6 wt. $\% \mathrm{H}_{2}$.

Hydrogen release was measured from a concentrated (23 wt.\%) $\mathrm{NaB}_{3} \mathrm{H}_{8}$ solution, which corresponds to the composition described by Eq 4. The solution was injected into a flask at room temperature containing $5 \mathrm{~mol} \% \mathrm{CoCl}_{2}$ as a pre-catalyst. The results (Fig. 3) showed a rapid release of 8 equivalents of $\mathrm{H}_{2}$, corresponding to a hydrogen generation rate of $1 \mathrm{gs}^{-1}$ for a $1 \mathrm{~L}$ reactor. The fluctuations in the curve before 1 minute including the overshoot past 8 equivalents are a consequence of the heat released from $\mathrm{CoCl}_{2}$ reduction and hydrogen release, which caused gas expansion more rapidly than could be compensated by the burette's thermocouples. ${ }^{24}$ The total $\mathrm{H}_{2}$ measured is less than the 9 equivalents or $6.5 \mathrm{wt} . \%$ of $\mathrm{H}_{2}$ expected theoretically by equation 4. The difference is due to some of the $\mathrm{B}_{3} \mathrm{H}_{8}{ }^{-}$being used to generate the active Co nanoparticle catalyst from $\mathrm{CoCl}_{2}$. Although reduction using $\mathrm{B}_{3} \mathrm{H}_{8}{ }^{-}$has not been extensively studied, comparison with the more widely used $\mathrm{BH}_{4}{ }^{-}$suggests that each $\mathrm{M}^{2+}$ ion results in one fewer $\mathrm{H}_{2}$ molecule and the maximum hydrogen expected from our experiment is therefore 8.5 equivalents. ${ }^{25}$ Once the catalyst has been reduced, subsequent hydrolyses are likely to deliver the expected $6.5 \mathrm{wt} . \% \mathrm{H}_{2}$. Since the engineering requirements for generating hydrogen from a liquid at room temperature are relatively modest, this provides a good basis for meeting the system target of $4.5 \mathrm{wt} . \% \mathrm{H}_{2}$.

${ }^{11} \mathrm{~B}$ NMR spectroscopy of the hydrolysis products showed broad peaks corresponding to a range of different products (Figure 4), which is consistent with our hypothesis of multiple polyborane anions. The peaks at $+18,+13$, and $+1 \mathrm{ppm}$ can be assigned to $\mathrm{B}(\mathrm{OH})_{3} / \mathrm{B}(\mathrm{OH})_{4}$, $\mathrm{B}_{3} \mathrm{O}_{3}(\mathrm{OH})_{4}^{-}$, and $\mathrm{B}_{5} \mathrm{O}_{6}(\mathrm{OH})_{4}{ }^{-}$respectively. ${ }^{16,26}$ The peaks are broadened because of rapid exchange between the different borate sites in the polyborate anions. The tetraborate dianion, $\mathrm{B}_{4} \mathrm{O}_{5}(\mathrm{OH})_{4}{ }^{2-}$, and triborate dianion, $\mathrm{B}_{3} \mathrm{O}_{3}(\mathrm{OH})_{5}{ }^{2-}$, give very broad resonances which are not observed in ${ }^{11} \mathrm{~B}$ NMR spectra. None of the starting $\mathrm{NaB}_{3} \mathrm{H}_{8}$ remained, which has a characteristic 9-line resonance near -31 ppm.

\section{Conclusions}


In this work we described a rational approach to determine the 'practical' hydrogen storage capacity, i.e., the hydrogen storage capacity of a liquid material that remains liquid throughout, by determining the most soluble polyborate solution as a function of the sodium to boron ratio. This reverse engineering approach, i.e., starting with the most soluble mixture of polyborate anions and working backward to choose the corresponding borohydride provides an approach to maximize the hydrogen storage capacity of a liquid phase borohydride carrier. The greatest solubility occurs when the ratio of $\mathrm{Na} / \mathrm{B}$ is between $0.25-0.35$ as a result of (i) a mixture of polyborate products that are formed resulting in meta-stable solutions with slow crystallization kinetics and (ii) condensation reactions that produce water to replace the water that is consumed to generate hydrogen. We show that hydrolysis of a $23 \mathrm{wt} \%$ solution of $\mathrm{NaB}_{3} \mathrm{H}_{8}$ provides a liquid carrier capacity of $6.5 \mathrm{wt} \%$ hydrogen. Further work to investigate the solubility of other ionic polyborates, e.g., $\mathrm{Li}, \mathrm{NH}_{4}, \mathrm{Mg}, \mathrm{Ca}$, could lead to the discovery of other octahydroborates that could further increase the hydrogen storage capacity while maintaining a liquid phase from beginning to end. This work teaches that it is advantageous to obtain a mixture of products to optimize solubility and minimize unwanted crystallization of highly concentrated solutions of boron hydride hydrolysis products.

Acknowledgements. The authors would like to thank Jim Sisco and Paul Osenar of Protonex Inc. for useful discussion regarding liquid hydrogen storage materials for portable power applications and the U.S. DoE Office of Energy Efficiency and Renewable Energy Fuel Cell Technologies Office for their continued interest in liquid hydrogen storage carriers. Pacific Northwest National Laboratory is a multi-program national laboratory operated for DOE by Battelle. The authors dedicate the work to the memory of Professor Sheldon Shore. His contributions to boron hydride chemistry set the foundation for many who have followed.

\section{$\underline{\text { References }}$}

${ }^{1}$ See section 3.3 Hydrogen Storage in the Fuel Cell Technologies Office Multi-Year Research, Development, \&Demonstration Plan - http://energy.gov/sites/prod/files/2014/03/f12/storage.pdf

${ }^{2}$ Bluhm M.E., Bradley M.G., Butterick R., Kusari U., Sneddon L.G. Amineborane-based chemical hydrogen storage: enhanced ammonia borane dehydrogenation in ionic liquids. J Am Chem Soc. 2006, 128, 7748. 
${ }^{3}$ Wright, W.R.H., Berkeley, E.R., Alden, L.R.; Baker, R.T, Sneddon, L.G.Transition metal catalysed ammonia-borane dehydrogenation in ionic liquids. Chem Comm. 2011, 47, 31777.

${ }^{4}$ Brayton, D.F.; Jensen, C.M. Solvent free selective dehydrogenation of indolic and carbazolic molecules with an iridium pincer catalyst. Chem. Comm. 2014, 50, 5987.

${ }^{5}$ Pez, G. P.; Scott, A. R.; Cooper, A. C.; Cheng, H.; Bagzis L. D.; Appleby J. B. WO 2005/000457, 2005.

${ }^{6}$ Graetz, J., Wolstenholme, D., Pez, G., Klebanoff, L., McGrady,S., Cooper. A., Ed. Lennie Klebanoff. Hydrogen Storage Technology Materials and Applications CRC Press 2013, Chapter 8. Development of off-board reversible hydrogen storage materials.

${ }^{7}$ Luo, W., Campbell, P.G., Zakharov, L. N., Liu, S-Y. A Single-Component Liquid-Phase Hydrogen Storage Material. J. Am. Chem. Soc. 2011, 133, 19326

8 Luo, W; Neiner, D; Karkamkar, A ; Parab, K; Garner, EB; Dixon, DA; Matson, D; Autrey, T; Liu, SY. 3-Methyl-1,2-BN-cyclopentane: a promising H-2 storage material? . Dalton Trans. 2013, 42, 611-614.

${ }^{9}$ Ahluwalia, R.K., Peng, J.K., Hua, T.Q. Hydrogen release from ammonia borane dissolved in an ionic liquid. Int. J. Hydrogen Energy. 2011, 36, 15689.

${ }^{10}$ Demirci, U.B., Miele, P. Sodium borohydride versus ammonia borane, in hydrogen storage and direct fuel cell applications. Energy Environ. Sci., 2009, 2, 627.

${ }^{11}$ Li, L., Li, S., Tan, Y., Tang, Z., Cai, W., Guo, Y., Li, Q., Yu, X. Hydrogen Generation from Hydrolysis and Methanolysis of Guanidinium Borohydride. J. Phys. Chem. C 2012, 116, 14218.

${ }^{12}$ Chandra, M., Xu, Q.. A high-performance hydrogen generation system: Transition metalcatalyzed dissociation and hydrolysis of ammonia-borane. Journal of Power Sources 156 (2006) 190-194.

${ }^{13}$ Moussa, G., Moury, R., Demirci, U.B., Miele, P. Borates in hydrolysis of ammonia borane. Int. J. Hydrogen Energy, 2013, 38, 7888.

${ }^{14}$ Zhang, Q., Wu, Y., Sun, X., Ortega, J. Kinetics of Catalytic Hydrolysis of Stabilized Sodium Borohydride Solutions. Ind. Eng. Chem. Res. 2007, 46, 1120-1124

${ }^{15}$ Kirk-Othmer Encyclopedia of Chemical Technology. Wiley 2011 Boron Oxides, Boric Acid, and Borates by D. Schubert . DOI:10.1002/0471238961.0215181519130920.a01.pub3

${ }^{16}$ Salentine. C.G. High-Field ${ }^{11}$ B NMR of Alkali Borates. Aqueous Polyborate Equilibria. Inorg. Chem 1983, 26, 3921.

${ }^{17}$ Shore, S. Studies of the Smaller Boron Hydrides and their Derivatives. Pure \& Appl. Chem., $1977,49,717$.

${ }^{18}$ Beall, H., Gaines, D.F. Mechanistic aspects of boron hydride reactions. Inorganica Chimica Acta. 1999, 289, 1.

${ }^{19}$ Huang, Z., Chen, X., Yisgedu, T., Zhao, J-C., Shore, S.G. High-capacity hydrogen release through hydrolysis of $\mathrm{NaB}_{3} \mathrm{H}_{8}$. Int. J. Hydrogen Energy. 2011, 36, 7038-42.

${ }^{20}$ Huang, Z., Chen,X., Yisgedu, T., Meyers, E.A., Shore, S,G., Zhao, J-C. Ammonium Octahydrotriborate $\left(\mathrm{NH}_{4} \mathrm{~B}_{3} \mathrm{H}_{8}\right)$ : New Synthesis, Structure, and Hydrolytic Hydrogen Release. Inorg. Chem. 2011, 50, 3738-3742.

${ }^{21}$ Huang, Z., King, G., Chen, X., Hoy, J., Yisgedu, T., Lingam, H.K., Shore, S.G., Woodward, P.M., Zhao, J-C. A Simple and Efficient Way to Synthesize Unsolvated Sodium

Octahydrotriborate Inorg. Chem. 2010, 49, 8185-8187.

${ }^{22}$ Titov, L.V. Synthesis and chemical transformations of ionic octahydrotriborates of the B3H8 anion. Russian J. Inorg. Chem. 2003, 48, 1613. 
${ }^{23}$ Chong, M., Karkamkar, A., Autrey, T., Orimo, S., Jalisatgi, S., Jensen, C.M. Reversible dehydrogenation of $\mathrm{Mg}\left(\mathrm{BH}_{4}\right)_{2}$ to $\mathrm{Mg}\left(\mathrm{B}_{3} \mathrm{H}_{8}\right)_{2}$ in the solid state under moderate conditions. Chem Comm. 2011, 47,1330.

${ }^{24}$ Zheng, F., Rassat, S.D., Heldebrant, D.J., Caldwell, D.D., Aardahl, C.L., Autrey, T., Linehan, J.C., Rappé, K.G. Automated gas burette system for evolved hydrogen measurements. Review Scientific Instruments 2008, 79, 084103

${ }^{25} \mathrm{Li}$, Y., Cao, Y., Jia, D. A general strategy for synthesis of metal nanoparticles by a solid-state redox route under ambient conditions. J. Mater. Chem. A, 2014, 2, 3761

${ }^{26}$ Yoon, C.W., Carroll, P.J., Sneddon, L.G. Ammonia Triborane: A New Synthesis, Structural Determinations, and Hydrolytic Hydrogen-Release Properties. J. Am. Chem. Soc. 2009, 131, 855. 

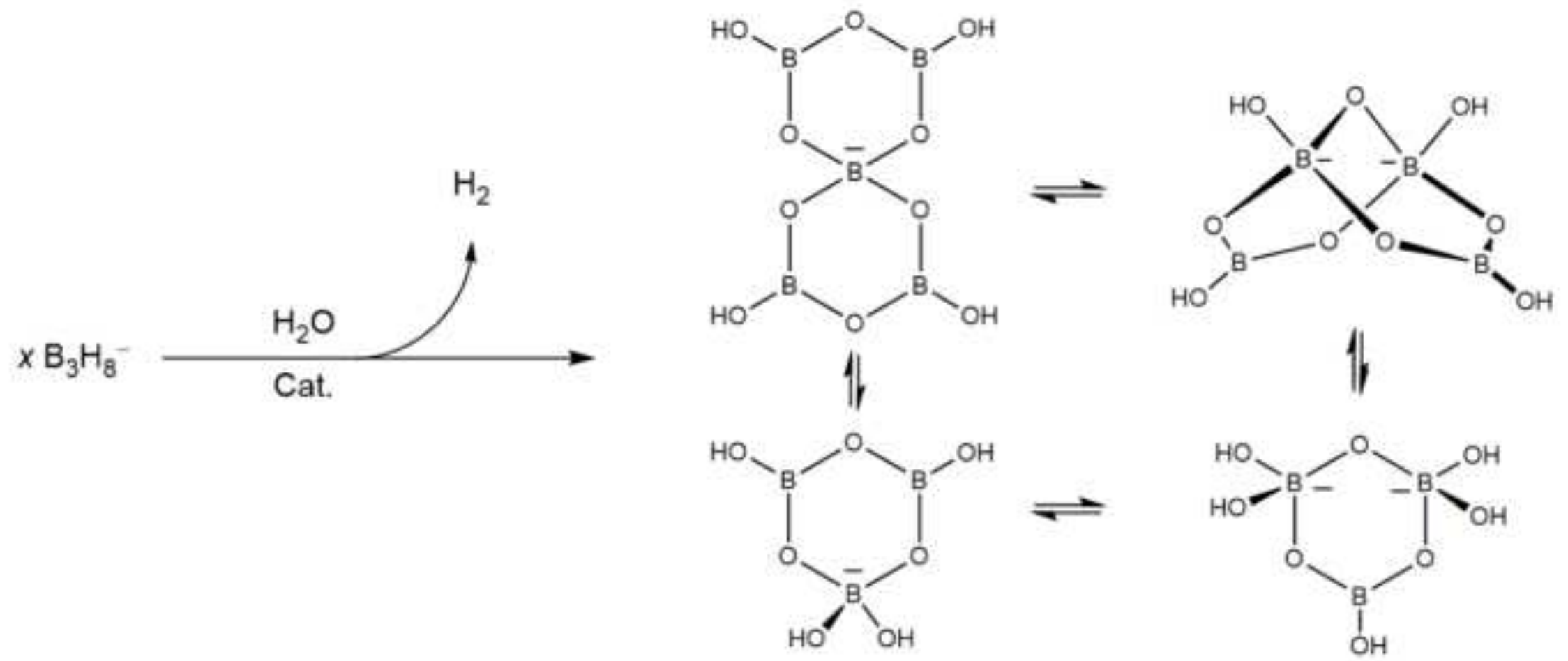


\section{Capacity Enhancement of Aqueous Borohydride Fuels for hydrogen storage in liquids}

David Schubert, Doinita Neiner, Mark Bowden, Sean Whittemore, Jamie Holladay, Zhenguo Huang and Tom Autrey

Figures and Tables

Table 1. Aqueous sodium borate solutions representing spent fuel at various concentrations. The wt. fraction $\mathrm{H}_{2}$ is calculated for the corresponding borohydride solutions.

\begin{tabular}{cccccl}
\hline $\mathrm{NaOH}(\mathrm{g})$ & $\mathrm{B}(\mathrm{OH})_{3}(\mathrm{~g})$ & $\mathrm{H}_{2} \mathrm{O},(\mathrm{g})$ & $\mathrm{Na} / \mathrm{B}$ & Wt frac $\mathrm{H}_{2}$ & Appearance \\
\hline 31.65 & 48.93 & 45.5 & 1.0 & $4.82 \%$ & Clear \\
31.65 & 48.93 & 41.0 & 1.0 & $4.99 \%$ & Clear \\
31.65 & 48.93 & 35.2 & 1.0 & $5.22 \%$ & Solids \\
4.82 & 21.99 & 11 & 0.34 & $5.40 \%$ & Clear \\
4.82 & 21.9 & 5 & 0.34 & $6.35 \%$ & Cloudy \\
4.7 & 23.25 & 3.2 & 0.31 & $6.74 \%$ & Viscous, but stirrable \\
\hline
\end{tabular}


Figure 1. Plot of solubility of sodium polyborate solutions $\left(\mathrm{B}_{2} \mathrm{O}_{3}\right)$ as a function of $Q=\mathrm{Na} / \mathrm{B}$ ratio. The highest solubility of borates is between $\mathrm{Q}=0.25$ and 0.33 ). At $\mathrm{Q}=1$, e.g., hydrolysis of $\mathrm{NaBH}_{4}$ to yield $\mathrm{NaB}(\mathrm{OH})_{4}$ solubility limit at $60{ }^{\circ} \mathrm{C}$ is ca. $20 \mathrm{wt} \% \mathrm{~B}_{2} \mathrm{O}_{3}$ compare to $\mathrm{Q}=0.31$ where solubility is ca. $40 \mathrm{wt} \% \mathrm{~B}_{2} \mathrm{O}_{3}$.

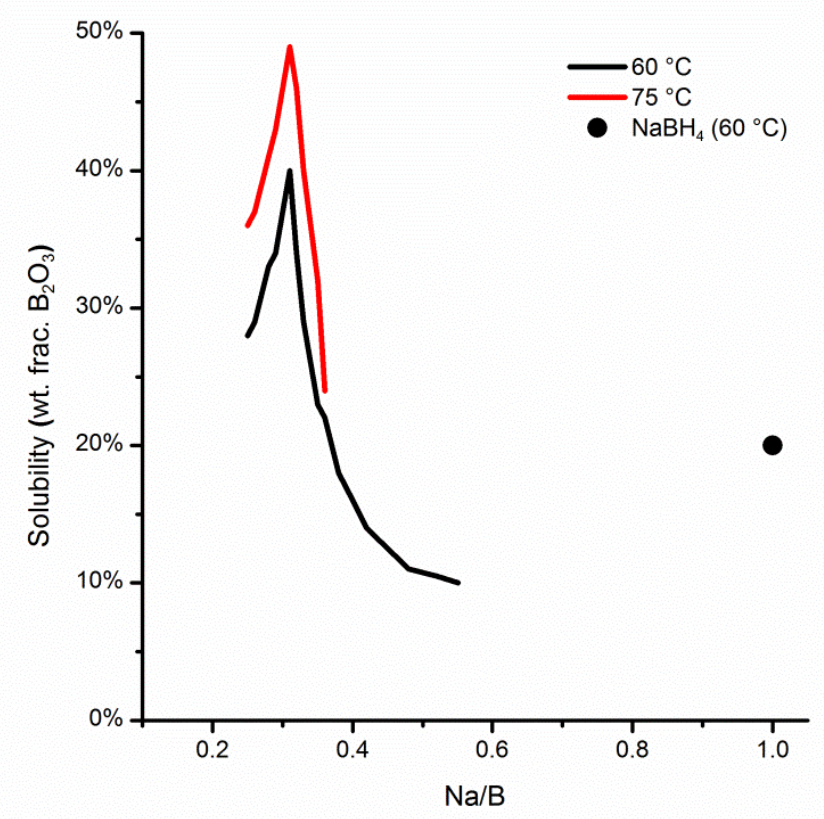


Figure 2. Aqueous sodium polyborate solution $(\mathrm{Na} / \mathrm{B}=0.34)$ simulating spent fuel after release of $6.35 \mathrm{wt} . \% \mathrm{H}_{2}$ cooled to room temperature.

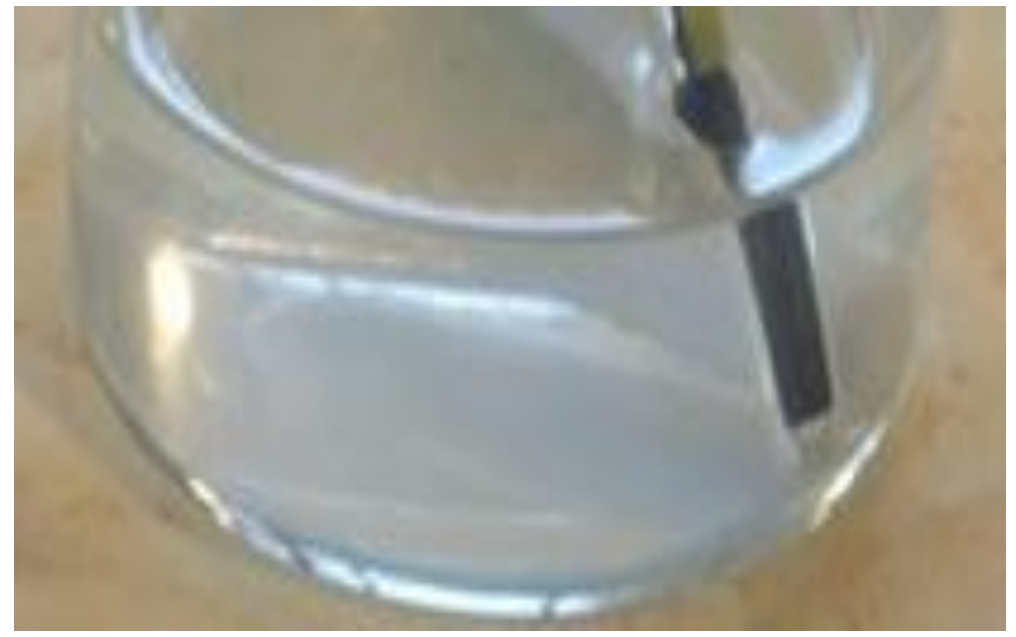


Figure 3. Hydrogen release from a 23 wt. $\%$ solution of $\mathrm{NaB}_{3} \mathrm{H}_{8}$ with $5 \mathrm{~mol} \% \mathrm{CoCl}_{2}$ catalyst, measured by gas burette at room temperature.

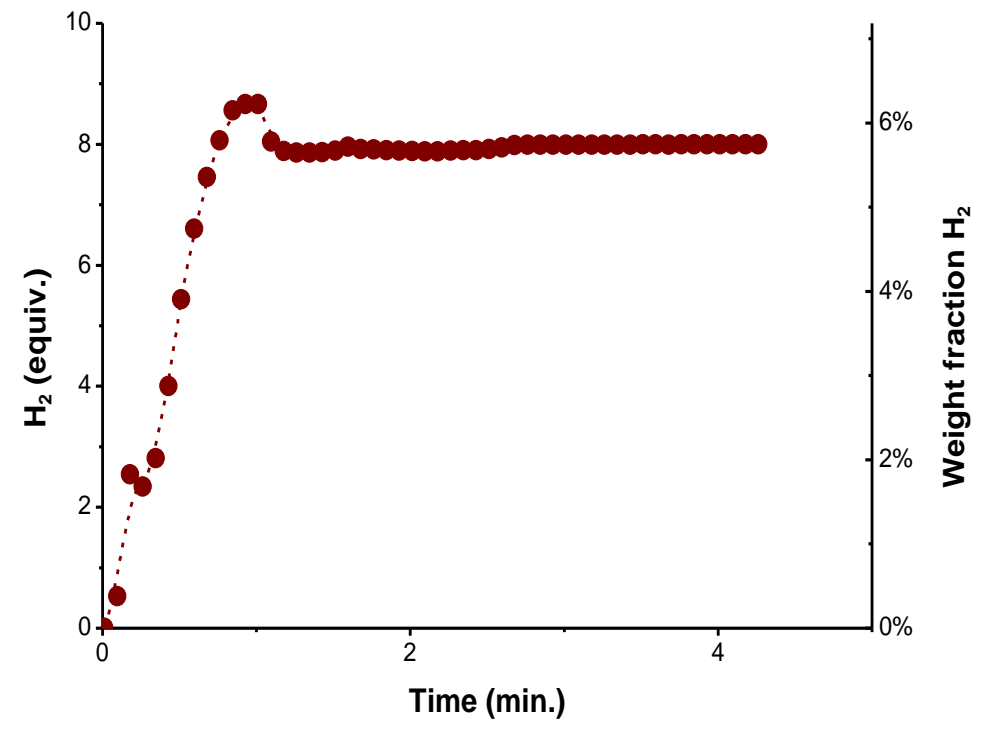


Figure 4. (A) ${ }^{11} \mathrm{~B}$ NMR spectrum of $\mathrm{NaB}_{3} \mathrm{H}_{8}$ hydrolysis products, broad peak centered $\sim+15$ $\mathrm{ppm}$ is due to mixture of polyborate products, $\mathrm{B}_{3} \mathrm{O}_{3}(\mathrm{OH})_{5}{ }^{2-}, \mathrm{B}_{4} \mathrm{O}_{5}(\mathrm{OH})_{4}{ }^{2-}, \mathrm{B}_{3} \mathrm{O}_{3}(\mathrm{OH})_{4}{ }^{-}$, $\mathrm{B}_{5} \mathrm{O}_{6}(\mathrm{OH})_{4}{ }^{-}$, peak at $+2 \mathrm{ppm}$ is $\mathrm{B}(\mathrm{OH})_{4}{ }^{-}$. (B) ${ }^{11} \mathrm{~B}$ NMR spectrum of $\mathrm{NaB}_{3} \mathrm{H}_{8}$ starting material before addition of catalyst showing characteristic nonet at $-31 \mathrm{ppm}$ due to coupling with eight equivalent hydrogens.

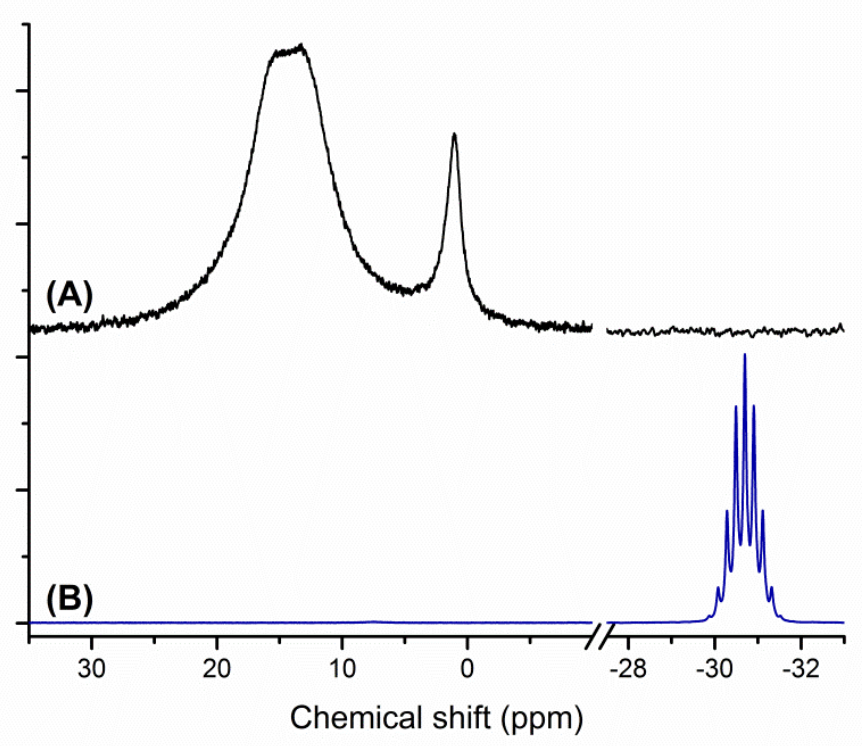

